\title{
Three new Xanthoria species from South Africa: X. hirsuta, X. inflata and X. doidgeae
}

Eichenberger, Christof ; Aptroot, André ; Honegger, Rosmarie

\begin{abstract}
Three new <jats:italic $>$ Xanthoria $</$ jats:italic $>$ species are described from South Africa. $<$ jats:italic $>$ Xanthoria hirsuta $</$ jats:italic $>$ sp. nov. has hairs on the surface of the thallus and apothecia, best visible in young, growing parts. Dust particles and sand granules stick to this hairy surface, giving the thallus a somewhat dirty appearance. <jats:italic $>$ Xanthoria inflata $</$ jats:italic $>$ sp. nov. has inflated lobes similar to a $<$ jats:italic $>$ Menegazzia $</$ jats:italic $>$. It carries numerous crystals on its medullary hyphae, which are ivory-coloured in young, but intensely orange coloured in old lobes. $<$ jats:italic $>$ Xanthoria doidgeae $</$ jats:italic $>$ sp. nov. has relatively small lobes with pruinose margins. All three species are fertile, none of them forms symbiotic propagules.
\end{abstract}

DOI: https://doi.org/10.1017/s0024282907006962

Posted at the Zurich Open Repository and Archive, University of Zurich ZORA URL: https://doi.org/10.5167/uzh-154904

Journal Article

Published Version

Originally published at:

Eichenberger, Christof; Aptroot, André; Honegger, Rosmarie (2007). Three new Xanthoria species from South Africa: X. hirsuta, X. inflata and X. doidgeae. The Lichenologist, 39(05):451-458.

DOI: https://doi.org/10.1017/s0024282907006962 


\title{
Three new Xanthoria species from South Africa: X. hirsuta, $X$. inflata and $X$. doidgeae
}

\section{Christof EICHENBERGER, André APTROOT and Rosmarie HONEGGER}

\begin{abstract}
Three new Xanthoria species are described from South Africa. Xanthoria hirsuta sp. nov. has hairs on the surface of the thallus and apothecia, best visible in young, growing parts. Dust particles and sand granules stick to this hairy surface, giving the thallus a somewhat dirty appearance. Xanthoria inflata sp. nov. has inflated lobes similar to a Menegazzia. It carries numerous crystals on its medullary hyphae, which are ivory-coloured in young, but intensely orange coloured in old lobes. Xanthoria doidgeae sp. nov. has relatively small lobes with pruinose margins. All three species are fertile, none of them forms symbiotic propagules.
\end{abstract}

Key words: hairy thallus surface, Lecanoromycotina, medullary secondary compounds, Teloschistaceae, Trebouxia photobiont

\section{Introduction}

The South African Cape Flora appears to be a centre of diversity not only among angiosperms, but also among lichen-forming ascomycetes. Within the genus Xanthoria (Teloschistaceae, Lecanoromycotina) several endemic species are known to science, some of them having a very small area of distribution (Doidge 1950; Kärnefelt 1989; Kärnefelt et al. 1995, 2002; Kondratyuk et al. 2004). Here we describe three new Xanthoria species, which had been collected by botanists on field trips devoted to studies on angiosperms. Sequence data (multilocus approach) were obtained for all three species; these will be published in a separate study on the phylogeny of Teloschistaceae of the Southern Hemisphere (C. Eichenberger et al., unpublished).

C. Eichenberger and R. Honegger: Institut für Pflanzenbiologie, Universität Zürich, Zollikerstrasse 107, CH-8008 Zürich, Switzerland. E-mail: rohonegg@botinst.unizh.ch

A. Aptroot: ABL Herbarium, Gerrit van der Veenstraat 107, NL-3762 XK Soest, The Netherlands.

\section{Materials and Methods}

All specimens were kept in the desiccated state at $-20^{\circ} \mathrm{C}$ where they retain their full viability (Honegger 2003) until completion of ongoing experiments in summer 2007. Vouchers will be deposited in the herbaria of the University and Swiss Federal Technical Institute (ETH) Zürich $(\mathrm{Z}+\mathrm{ZT})$.

Additional species studied: Xanthoria capensis Kärnefelt, Arup \& L. Lindblom, South Africa: Noordhoek Beach, Cape Town, 25 iii 2002. A. Möhl (voucher 306 det. R. Honegger).

Xanthoria flammea (L. f.) Hillmann, South Africa: West coast, 1 iii 2000, R. Dudler (Voucher 2, det. R. Honegger); West coast, 1 ii 1999, E. Ruiz \& H. P. Ruffner (voucher 101, det. R. Honegger); Western Cape, Vredenburg, 14 ix 2006, F. Supthut (voucher 485, det. R. Honegger).

Xanthoria karrooensis S. Kondratyuk \& Kärnefelt, South Africa: Western Cape, Van Rhynsdorp, 3 x 2002, H. Gansner (voucher 359, det. H. Gansner \& R. Honegger); Western Cape, Van Rhynsdorp, 3 x 2002, H. Gansner (voucher 360I, det. H. Gansner \& R. Honegger); Western Cape, Lamberts Bay, 22 ix 2003, D. F. Supthut (voucher 423I+III, det. R. Honegger).

Xanthoria turbinata Vain. South Africa: Port Nolloth, 1 iii 2000, R. Dudler (voucher 3, det. R. Honegger). Namibia: Cape Cross, Sept. 2000, P. D. Crittenden (voucher 108, det. R. Honegger); Fog Desert, Old Windhoek road, $28 \times 2006$, A. Aptroot (voucher 491, det. A. Aptroot).

\section{Microscopy}

Light microscopy. Hand-cut sections were mounted in tap water. Semi-thin sections were cut with glass knives 
from chemically fixed, dehydrated specimens which had been infiltrated with and embedded in methacrylate (HISTORESIN Leica, Heidelberg).

Scanning electron microscopy. Specimens were either air dried, or critical point dried after chemical fixation in osmium tetroxide and dehydration in acetone. Protoplasts were removed from dissected samples by incubation in a saturated solution of the commercially available washing powder ARIEL Regular (Procter \& Gamble, Cincinnati USA) prior to chemical fixation. After sputter-coating with gold the specimens were examined with a HITACHI Stereoscan field emission microscope.

\section{Thin layer chromatography (TLC)}

Secondary metabolites were extracted from dry lichens with a few drops of $100 \%$ acetone. $0 \cdot 2 \mathrm{~mm}$ silica gel 60 F254 pre-coated TLC aluminium sheets were used as stationary phase (MERCK 5554). 17 parts toluene p.a. (Riedel-de Haën) mixed with 3 parts of $100 \%$ acetic acid (glacial) p.a. (MERCK) were used as mobile phase (solvent $\mathrm{C}$ according to Huneck and Yoshimura 1996). The separation of substances was analysed with short and long wavelength UV light (254 nm or $350 \mathrm{~nm}$, respectively), or with a CAMAG TLC scanner 3. In addition, anthraquinones were tested on the TLC plates with $\mathrm{KOH}$ (purple colouration). Parietin (=Physcion ROTH 7412) and Emodin (FLUKA 47170) served as reference substances for Rf values (Huneck \& Yoshimura 1996).

\section{The Species}

\section{Xanthoria hirsuta Eichenberger, Aptroot \& Honegger sp. nov.}

Xanthoria parva thallo et apotheciis hirsutis, lobis maculatis.

Typus: South Africa, Western Cape, De Hoop, epiphytic, 10 October 2002, H. Gansner 360 II (Z+ZTholotypus).

\section{(Figs 1C \& D, 2A-F)}

Thallus small, 1-4 cm across, adpressed, yellow; lobes irregularly branched, up to $2 \mathrm{~mm}$ long and c. $1.5 \mathrm{~mm}$ wide, flat or usually slightly convex (Fig. 1C); in section 100-150 $\mu \mathrm{m}$ thick (Fig. 2F), margin thicker, up to $250 \mu \mathrm{m}$ and with dispersed hyaline hairs up to $50 \mu \mathrm{m}$ long and $10 \mu \mathrm{m}$ wide, which are covered with dust, sand granules and other particles (maculae) giving the thallus surface a dirty appearance (Fig. 2A \& B).
Hairs are most clearly visible at growing lobe margins and on young apothecia; they often stick to each other, thus forming soft, spinelike structures (Fig. 2A \& E), but collapse on older thalline areas (Fig. 2A \& F). Upper cortex $10-15 \mu \mathrm{m}$ thick, true paraplectenchymatous, covered with yellow crystals; algal layer 15-25 $\mu \mathrm{m}$ thick; photobiont Trebouxia sp., mycobiont-photobiont interface: intraparietal haustoria (Fig. 2F); medulla rather lax, composed of a network of smooth hyphae $2-3 \mu \mathrm{m}$ thick, without crystals or oil droplets; lower cortex more or less smooth, locally with very short hyphal protrusions (Fig. 2D \& F), whitish, 15-20 $\mu \mathrm{m}$ thick, true paraplectenchymatous; hapters rare and mainly laminal.

Apothecia located in the central part of the thallus, usually covering the lobes, $c .0 \cdot 5-$ $1.5 \mathrm{~mm}$ diameter, regularly rounded to irregularly compressed owing to spatial problems in older thallus areas where numerous mature apothecia are bordering upon each other; disc darker orange than the thallus, urceolate when young, becoming and remaining flat when mature; thalline exciple with hairs similar to those on the thallus margin (Fig. 2B), in section paraplectenchymatous, filled with algae; true exciple up to $30 \mu \mathrm{m}$ thick at the uppermost part, 10 $20 \mu \mathrm{m}$ in the basal part, scleroplectenchymatous; hymenium 40-50 $\mu \mathrm{m}$ high; subhymenium up to $20 \mu \mathrm{m}$ thick; asci 35$45 \times 10-12 \mu \mathrm{m}$; paraphyses c. $2 \mu \mathrm{m}$ diam., the uppermost cells up to $7 \mu \mathrm{m}$ diam., sparingly with oil droplets, covered with yelloworange crystals; ascospores $13-15 \times 5-6 \mu \mathrm{m}$, fusiform with pointed ends, septum 4-5 $\mu \mathrm{m}$ thick (Fig. 2C).

Pycnidia abundant, reddish orange, 100 $200 \mu \mathrm{m}$ diam.; spermatia narrowly ellipsoid, $2 \cdot 0-2 \cdot 5 \times 0 \cdot 7-1 \cdot 0 \mu \mathrm{m}$.

Chemistry. Chemosyndrome A3 sensu Søchting (1997).

Note. This species differs from all other Xanthoria species by the small hairs on the thallus margin and apothecia and by the maculae. 

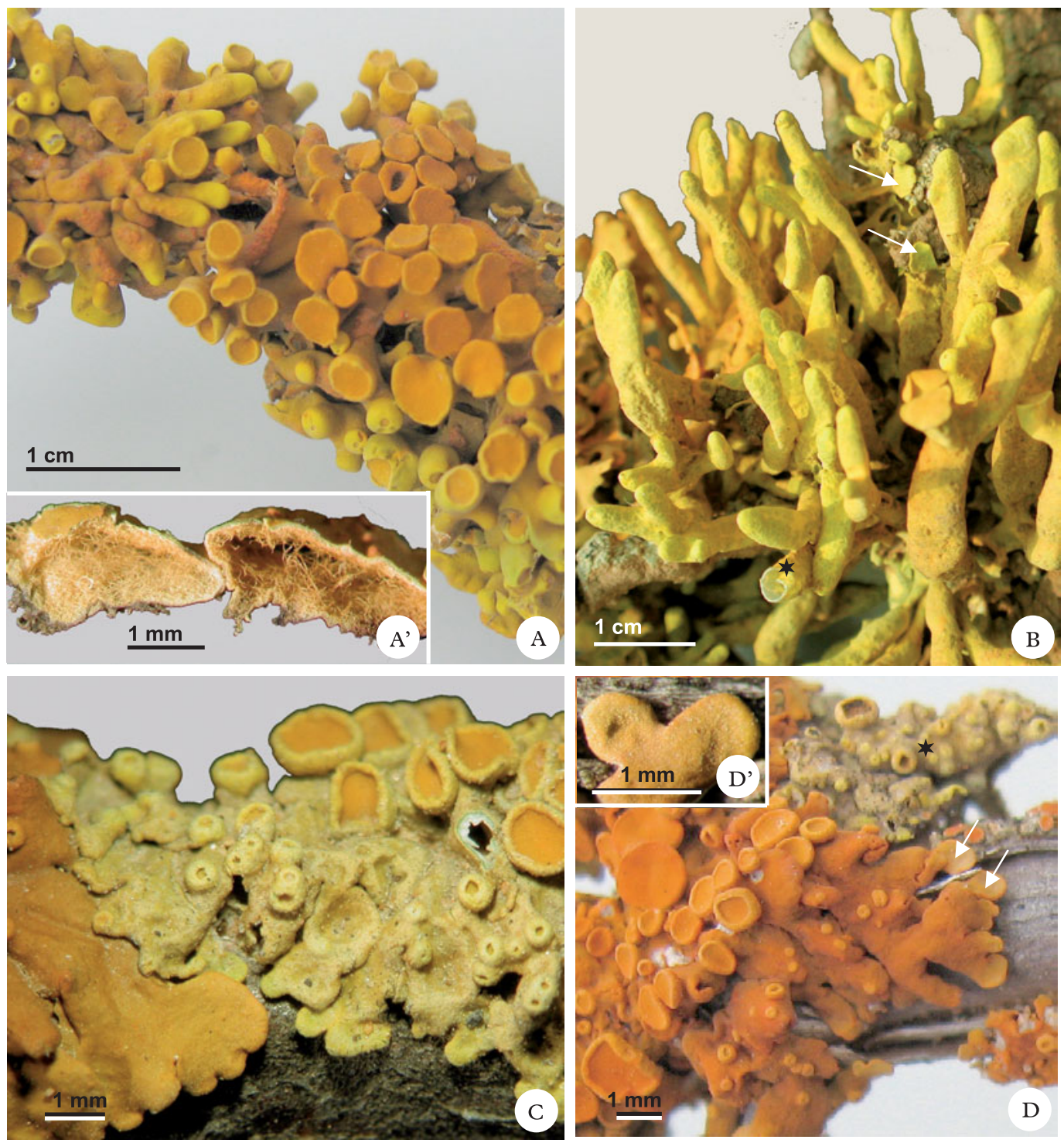

FIg. 1. Habitus of three new Xanthoria species from South Africa. A, X. inflata (voucher 483 I); A', cross section showing ivory-coloured medullary hyphae in young lobe (left) and orange-coloured medullary hyphae in old lobe (right); B, X. flammea, arrows point to young, foliose and dorsiventrally organized lobes which give rise to the tubular, erect growth form (asterisk indicates a broken, internally hollow tube); C, $X$. hirsuta (right; voucher 360 II) bordering upon $X$. karrooensis (left; voucher $360 \mathrm{I}$ ); D, $X$. doidgeae (left; voucher $481 \mathrm{I}$ ) bordering upon $X$. hirsuta (asterisk right, voucher 481 II), arrows point to pruinose peripheral lobes; D', detail of marginal lobe with pruinose upper surface. 

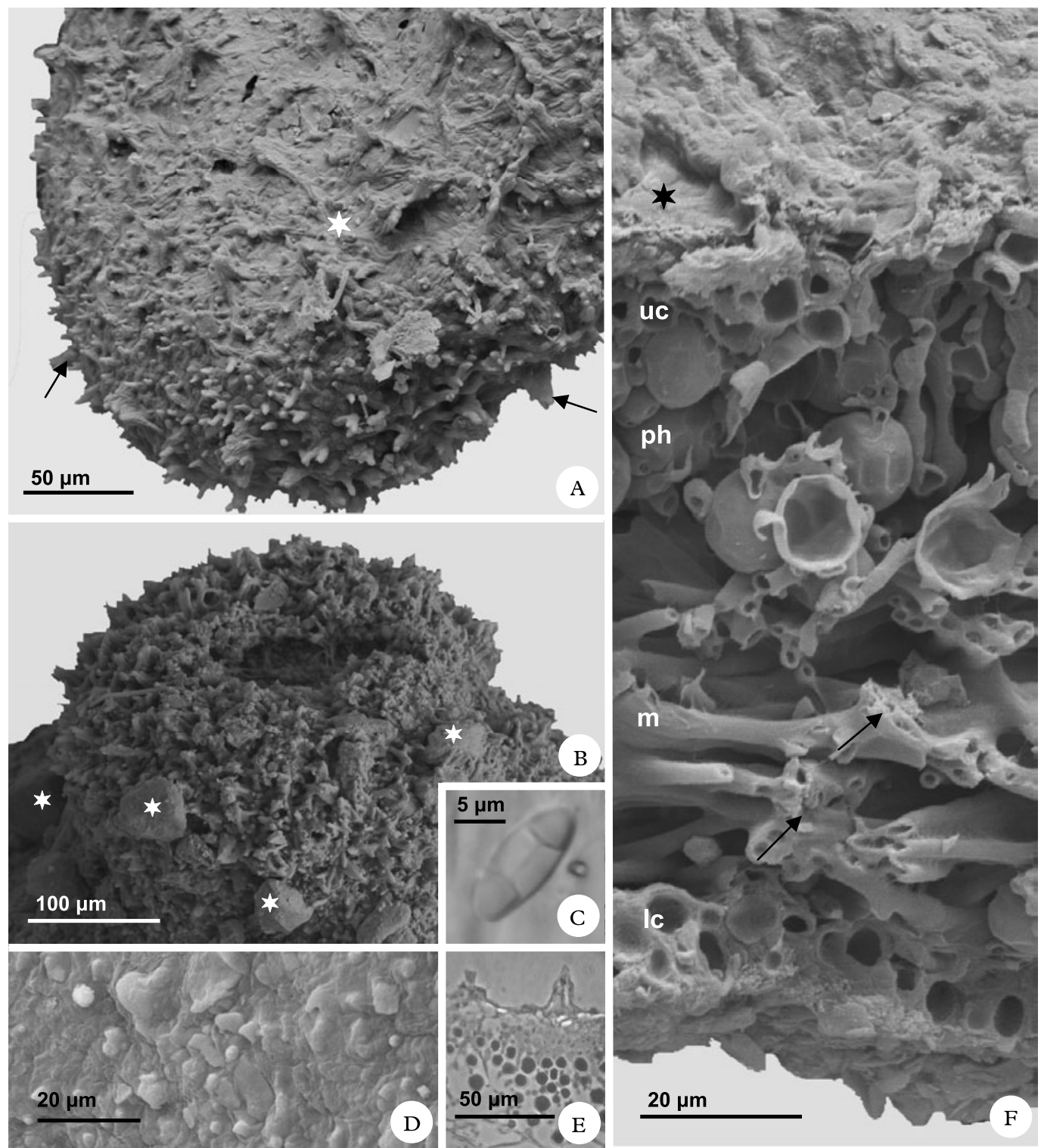

FIG. 2. Xanthoria hirsuta (voucher 360 II). A, hairy upper surface at the lobe margin, arrows point to groups of hairs sticking to each other and asterisk indicates collapsed hairs embedded in hydrophilic mucilage covering the whole thallus surface; B, hairy surface of young apothecium, with adhering sand granules (asterisks); C, ascospore; D, surface of lower cortex; E, cross-section of algal layer, upper cortex and a spine-like structure formed by a group of hairs sticking to each other; F, thallus cross-section with mucilaginous layer formed by collapsed hairs on the surface (asterisk); uc: upper cortex; ph: photobiont layer; m: medullary layer, arrows point to conglutinate hyphae; lc: lower cortex. A, B, D \& F, scanning electron micrographs; C \& E, light micrographs; E, semi-thin section of plastic-embedded specimen. 

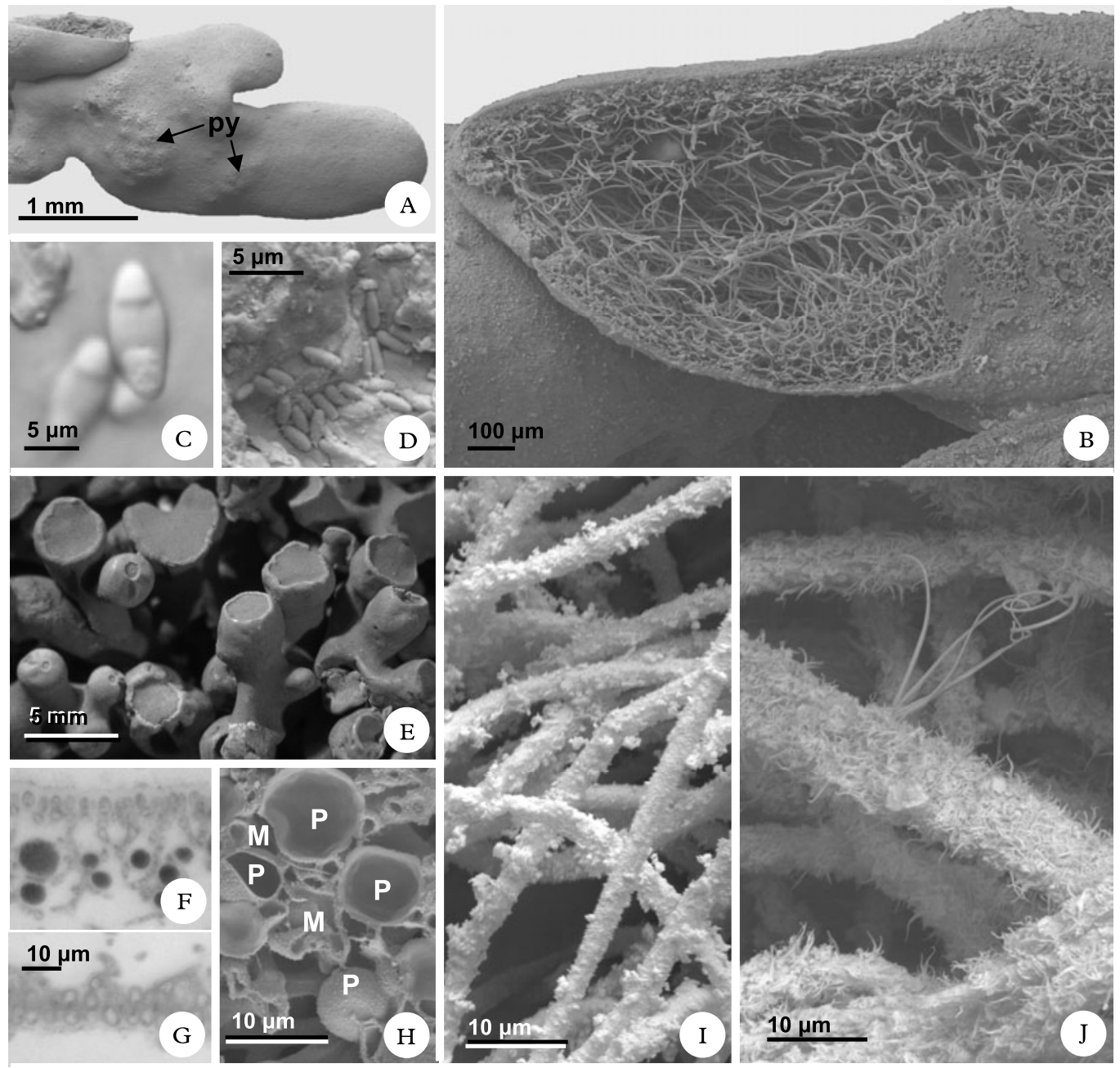

FIG. 3. Xanthoria inflata (voucher 483 I). A, habit, py indicates dense groups of pycnidia; B, cross-section, showing loose medullary hyphae; C, ascospores; D, spermatia (microconidia) on the ostiole of a pycnidium; E, ascomata at different developmental stages; F, algal layer and upper cortex; G, lower cortex; H, mycobiont-photobiont interaction; M: mycobiont; P: unicellular photobiont (Trebouxia sp.); I, medullary hyphae in a young lobe with comparatively few crystals; J, medullary hyphae in an old lobe with numerous, diverse crystals. A, B, D, E, H-J: scanning electron micrographs of conventionally prepared and air dried (I-J) specimens; C, F \& G: light micrographs, F-G: semithin sections of plastic-embedded samples.

Additional specimens examined. South Africa: Van Rhynsdorp, Quaggaskop, Knersvlakte, 2006, D. F. Supthut 481 II, $482(Z+Z T)$.

\section{Xanthoria inflata Eichenberger, Aptroot \& Honegger sp. nov.}

Xanthoria thallo inflato, medullis auranticis, apotheciis stipitatiis.
Typus: South Africa, Western Cape, Lamberts Bay, epiphytic, 3 September 2006, D. F. Supthut 483 I (Z+ZT-holotypus).

\section{(Figs 1A, 3A-J)}

Thallus rather fragile, $3-7 \mathrm{~cm}$ across, loosely adpressed, yellow-orange; lobes irregularly sparingly branched, up to $4 \mathrm{~mm}$ 

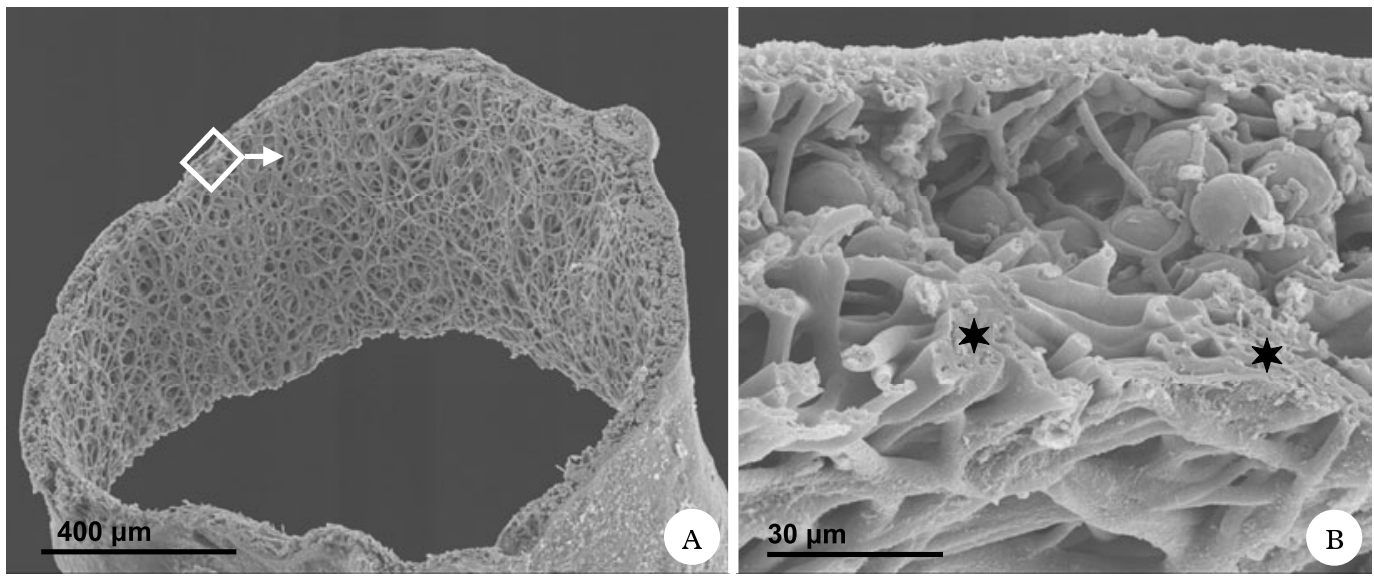

FIG. 4. Scanning electron micrographs of a fragment of the tubular part of Xanthoria flammea. A, overview; B, detail of cross-section, with strands of thick-walled medullary hyphae (asterisks) forming a conglutinate meshwork at the inner periphery of the tube.

long and $2 \mathrm{~mm}$ wide, convex, in section up to $2 \mathrm{~mm}$ thick (Fig. 1A); upper cortex 10$15 \mu \mathrm{m}$ thick, pseudoprosoplectenchymatous, covered with yellow crystals; algal layer 40-70 $\mu \mathrm{m}$ thick (Fig. 3F \& H); photobiont Trebouxia sp.; mycobiont-photobiont interface: intraparietal haustoria (Fig. $3 \mathrm{H}$ ); medulla lax, composed of loosely interwoven hyphae $4-5 \mu \mathrm{m}$ thick, which do not form conglutinate strands (Fig. 3B), but are covered with crystals (ivory in young, orange in old lobes; Figs 1A', 3I-J), without oil droplets; lower cortex scrobiculate, whitish, 10$15 \mu \mathrm{m}$ thick, true paraplectenchymatous (Fig. 3G); hapters not observed.

Apothecia located in central part of the thallus, turbinate, $c .1-3 \mathrm{~mm}$ diam., on $c$. 1-3 mm high, inflated stalks with yellow medulla, regularly rounded (Fig. 3E); disc darker yellow, remaining flat when mature (Figs 1A, 3E); thalline exciple curved inwards when young, crenate or pruinose where bordering the disc, in section paraplectenchymatous, filled with algae; true exciple up to $50 \mu \mathrm{m}$ thick at the uppermost part, 10$20 \mu \mathrm{m}$ in the basal part, scleroplectenchymatous; hymenium 40-50 $\mu \mathrm{m}$ high; subhymenium up to $40 \mu \mathrm{m}$ thick; asci 30$35 \times 10-12 \mu \mathrm{m}$; paraphyses c. $2 \mu \mathrm{m}$ diam., the uppermost cells up to $6 \mu \mathrm{m}$ diam., without oil droplets, covered with yellow-orange crystals; ascospores $11-12.5 \times 4.5-5.5 \mu \mathrm{m}$, fusiform with somewhat rounded ends, septum 4-5 $\mu \mathrm{m}$ thick (Fig. 3C).

Pycnidia abundant, often in groups, reddish orange, $100-200 \mu \mathrm{m}$ diam.; spermatia narrowly ellipsoid, $2.5-3.0 \times 1.0-1.5 \mu \mathrm{m}$ (Fig. 3D).

Chemistry. At the thallus surface predominantly parietin, on old, orange medullary hyphae an orange anthraquinone that needs further chemical analysis.

Note. This species differs from all other Xanthoria species by the inflated thallus, resembling a Menegazzia. It differs from Xanthoria flammea (L. f.) Hillmann [Xanthodactylon flammeum (L. f.) C. W. Dodge] (Figs 1B, 4A-B) by its growth form and its yellow medulla.

\section{Xanthoria doidgeae Eichenberger, Aptroot \& Honegger sp. nov.}

Xanthoria parva thallo pruinoso minutis scrobiculatis, apotheciis regularis, marginibus internis pruinosibus vel crenatibus.

Typus: South Africa, Western Cape, Van Rhynsdorp, Quaggaskop, Knersvlakte, epiphytic, 5 September 2006, D. F. Supthut 481 I (Z+ZT-holotypus).

$$
\text { (Figs 1D, 1D', 5A-F) }
$$



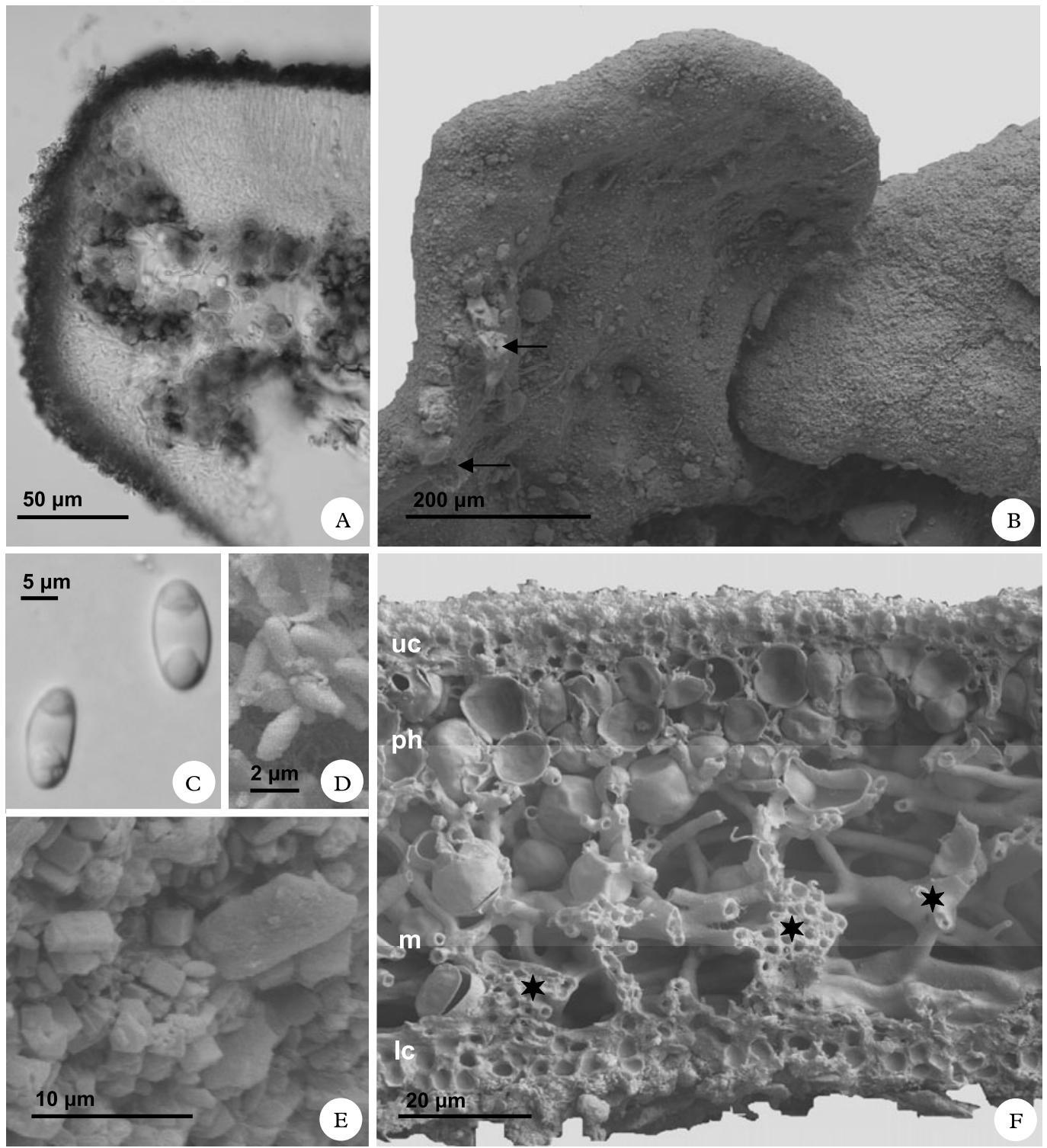

FIG. 5. Xanthoria doidgeae. A, cross-section of apothecial margin; B, peripheral lobes seen from their lower (left) and upper surface (right), arrows point to young marginal hapters; C, ascospores; D, spermatia (microconidia) in pycnidium; E, detail of pruina on the upper surface of a marginal lobe, with crystals of Ca-oxalate; F, cross-section of thallus, uc: upper cortex., ph: photobiont layer, m: medullary layer, asterisks indicate conglutinate hyphae, lc: lower cortex. A \& C: light micrographs. B, D \& F: scanning electron micrographs.

Thallus small, $1-3 \mathrm{~cm}$ across, tightly adpressed, various shades of orange; lobes irregularly branched, up to $4 \mathrm{~mm}$ long and $c$. $2 \mathrm{~mm}$ wide, generally flat but with some depressions and ridges, for example always along the margin, dull, pruinose (Figs. 1D \& D', 5B \& E); in section 50-100 $\mu \mathrm{m}$ thick (Fig. 5F), margin thicker, up to $150 \mu \mathrm{m}$; upper cortex 5-10 $\mu \mathrm{m}$ thick, true paraplectenchymatous, covered with yellow crystals; 
algal layer $20-40 \mu \mathrm{m}$ thick; photobiont Trebouxia sp.; mycobiont-photobiont interface: intraparietal haustoria (Fig. 5F); medulla rather lax, composed of a network of smooth hyphae 4-5 $\mu \mathrm{m}$ thick, some of them forming conglutinate strands, without crystals or oil droplets; lower cortex smooth, whitish, 10$15 \mu \mathrm{m}$ thick, true paraplectenchymatous (Fig. 5F); hapters rather rare and mainly laminal (Fig. 5B).

Apothecia located in central part of the thallus, usually covering the lobes, c. 0.5$1.5 \mathrm{~mm}$ diam., regularly rounded to irregularly compressed; disc various shades of orange, remaining flat when mature; thalline exciple curved inwards when young, crenate or pruinose where bordering the disc, in section paraplectenchymatous, filled with algae (Fig. 5A); true exciple up to $35 \mu \mathrm{m}$ thick in the uppermost part, $10-20 \mu \mathrm{m}$ in the basal part, scleroplectenchymatous; hymenium 50-60 $\mu \mathrm{m}$ high; subhymenium up to $20 \mu \mathrm{m}$ thick; asci 40-50 × 10-12 $\mu \mathrm{m}$; paraphyses $c$. $2 \mu \mathrm{m}$ diam., the uppermost cells up to $7 \mu \mathrm{m}$ diam., without oil droplets, covered with yellow-orange crystals; ascospores $12-14 \times 5$ $6 \mu \mathrm{m}$, fusiform-ellipsoid with rounded ends, septum 4-5 $\mu \mathrm{m}$ thick (Fig. 5C).

Pycnidia sparse, reddish orange, 100$150 \mu \mathrm{m}$ diam.; spermatia ellipsoid, 2.2$2.7 \times 1 \cdot 2-1.5 \mu \mathrm{m}$ (Fig. 5D).

Chemistry. Chemosyndrome A sensu Søchting (1997).

Note. This species differs from all other Xanthoria species known from South Africa and Australia by its small thalli, the irregularly micro-scrobiculate, pruinose lobes and the somewhat crenate inner apothecium margin. It is named in honour of Ethel Mary Doidge, an outstanding South African mycologist and author of the first Checklist of South African lichens (1950).

We thank our friends and colleagues, Heidi Gansner, a former diploma student of our institute and Diedrich J. Supthut, former director of the Swiss Succulent Collection in Zurich, who kindly collected fresh material on their field trips to South Africa, and also the Swiss National Science Foundation for generous financial support (grant Nr. 31-103860 to R.H.).

\section{REFERENCES}

Doidge, E. M. (1950) The South African fungi and lichens to the end of 1945. Bothalia 5: 1-1094.

Honegger, R. (2003) The impact of different long-term storage conditions on the viability of lichenforming ascomycetes and their green algal photobiont, Trebouxia spp. Plant Biology 5: 224-230.

Huneck, S. \& Yoshimura, I. (1996). Identification of Lichen Substances. Berlin: Springer.

Kärnefelt, I. (1989) Morphology and phylogeny in the Teloschistales. Cryptogamic Botany 1: 147-203.

Kärnefelt, E. I., Arup, U. \& Lindblom, L. (1995) Xanthoria capensis (Teloschistaceae), a new endemic species in the Cape Flora Kingdom. Bibliotheca Lichenologica 57: 253-264.

Kärnefelt, I., Kondratyuk, S., Søchting, U. \& Frödén, P. (2002) Xanthoria karrooensis and $X$. alexanderbaai (Teloschistaceae), two new lichen species from southern Africa. Lichenologist 34: 333-346.

Kondratyuk, S., Kärnefelt, I., Søchting, U. \& Arup, U. (2004) New species of Xanthoria (Teloschistaceae) from Southern Africa. Bibliotheca Lichenologica 88: 349-362.

Søchting, U. (1997) Two major anthraquinone chemosyndromes in Teloschistaceae. Bibliotheca Lichenologica 68: 135-144. 